\title{
ECOCRITICSM \\ AS THE DEVELOPMENT OF TEACHING MATERIALS IN LITERARY THEORIES AND APPRECIATION COURSES Ahmad Iklil Saifulloh ${ }^{1}$, Deni Mustopa ${ }^{2}$, \\ ${ }^{12}$ Universitas Islam Majapahit \\ *e-mail: cli188id@gmail.com
}

\begin{abstract}
Eco Criticism or known as Literary Ecology which was popularized by Greg Gerrad has become a rare scientific discourse if it synergizes with the Indonesian character of education which is one of the educational pillars of the ministry of education. The resonance of these two scientific clumps between environment and literature to be the main topic promoted to realize the value of character education no 16 which is concerned about environment. To achieve this goal, this research using research and development by Plomp in order to form a form of book materials of Eco criticism as applied literary in education. The results obtained in the application of the ecological characteristics of literature which include the main elements, namely Pollution, Position, Pastoral, Wilderness, Apocalypse, Dwelling, Animal, Future the earth in a form of field test for students are 87.42 and expert validation $92.3 \%$, media $95,3 \%$, and $92.3 \%$ language in the course of literary theory and appreciation of English language education, the Faculty of Teacher Training and Education, Majapahit Islamic University of Mojokerto.
\end{abstract}

\section{Keywords: Development of teaching materials, literary theories and appreciation, Eco Criticsm.}

\section{INTRODUCTION}

Strengthening character in education has been the president's main mission since 2016. In fact, he emphasized that character education is the spearhead of the national character revolution that is mentioned in the ideals of the Indonesian nation. The regulation in strengthening the character of education was clearly be implemented by the Minister of Education and Culture which is contained in the formulation of character education values, including: Religious, Honesty, Tolerance, Discipline, Hard Work, Creative, Independent, Democratic, Curiosity, National Spirit, Love the Motherland, Respect for Achievement, Friendly/ Communicative, Peace, Love to Read, Care for the Environment, Social Care, and Responsibility(Putry, 2019) Vise verse with the reality, due to the earth day at $22^{\mathrm{m}}$ April 2020, this research which is focuses on Eco criticism area as one of the solutions of the bad pollution in Indonesia. As a result of deforestation and peat lands, Indonesia has become a country the third largest polluter in the world after America and Chisna. From 85\% of emissions produced by Indonesia, comes from forest destruction and land conversion peat(Central Bureau of Statistics, 2019).

Various ways have been done by the government to tackle this environmental crisis, but the solutions taken by the government only are not enough. The root of the basic and long-term problem lies in the community's habit of caring for the environment. So, the aim of this research is to build up long term awareness of the important of good environment from an early age especially at school. In accordance with the government regulation in the Strengthening of Character Education, this research becomes a bridge to improve the regulation especially the regulation to care the environment. The need for curriculum development must be carried out in all lines of education, especially the outputs that support the government program.

Therefore, the researchers need to prepare a specific scientific output system to support good character in education specifically for the future teachers in Mojokerto. And most responsible ones is the university who produce the educators. The largest University in Mojokerto was Islamic University of Majapahit and there is faculty there namely; Teacher Training and Education, English Education study program, Islamic University of Majapahit Mojokerto at the Literary Appreciation course using the Eco Criticism approach to strengthen the character of the national values in Environmental Care sector. 


\section{VOL. 03 NO. 01 , JUNE 2021}

This research was the improvement of previous research that focused on improving writing skills using a literary ecology approach with the title " The Implementation of Eco Criticism Approach for Healthy Earth and Strengthen the English Writing Skill of Literary Appreciation Class at Islamic University of Majapahit - Mojokerto" (Saifulloh, 2019) as the basic foundation of further research that will be developed in this research. Previous research has had good implementation outputs, but there are several evaluations that need improvement, especially in the field of teaching materials as a guide for lecturers. So the focus of this research is about how to develop teaching materials with ecological literature approach at the course of "Literary Theories and Appreciation" used by the fifth semester student of English Education Program Faculty at Teacher Training and Education Islamic University of Majapahit Mojokerto. The expected result of this research is to provide new scientific field in the field of literary ecology as applied literature for teacher and students. The students as future research are expected to be able to recognize scientific tragedy that are more comprehensive and speak out about environment. And becomes the trigger for further lecturers and researchers to continue to develop this applied literature especially Eco Criticism in teaching materials so that it becomes a scientific culture with a sustainable academic atmosphere.

Eco Criticism emerged as a scientific study of the combination of literature and the environment in the mid-1990s. (Cunningham \& Storey, 2005) Eco Criticism or known as Literary Ecology is a term that comes from the Greek Oikos and Critics. Oikos means a home which is appear in our daily life as nature, and the metaphysical thing is the transcendental spirit in the earth's form. While Critics means judges who wanted that home always be beautiful and natural. (Garrard, 2012)

Since Eco Criticism is a new in scientific field, several researchers and literary critics use different approaches and methods to define the term Eco Criticism in various ways. However, because of their fundamental concerns are similar in terms of natural conditions and the environment which are increase in worsen condition, so the various approaches that focus on the relationship between humans and the earth begun to resonance as Eco Criticism.(Phillips, 1999)

Eco Criticism is a critique of literature to the environment from the perspective of interdisciplinary paradigm which is tried to analyze the environment to find a possible solution and criticize of the environmental situation. According to Garrard, Eco Criticism may not be eligible to contribute to the discourse on issues in ecology but this discourse must remain beyond the boundaries of the discipline and develop ecological literacy as far and as deep as possible. (Garrard, 2004) According to Garrard, Eco Criticism has several types and characteristics for scientific development and exploring paradigmatic concepts that must be implemented (Garrard, 2004)including:

Pollution, Eco Criticism aims to explain, explore, and even solve ecological problems in a broader sense. The first thing that must be present in literary ecology is the word "Pollution" which comes from the Latin Polluere which means polluting or actions that are considered to support contamination activities against the nature. This basic subject definition gradually turns into real objective in fact, especially the definition of environment. Pollution is an ecological problem that does not mention a substance or class of substances, but rather a normative claim that implies that there is too much of something that is in the wrong place or in the environment it should be.

Position, although environmentalism is relatively new as a social, political, and philosophical movement, there have been a number of different eco-philosophers who seem to be competing with each other as to join in a revolutionary synthesis. Position is a term that means the environmental conditions that exist on earth in general today. Position can also be understood as the position of the earth as an approach to understanding the environmental crisis in their own way, emphasizing aspects that produce solutions in terms of what they support or threaten the environment.

Pastoral, is the approach to literature where researchers use various techniques to locate and compare multiple environmental conditions in ancient times and now. For example, the natural conditions before and after the industrial revolution were packaged in past and present literary works. What's more, the industrial revolution 4.0 has penetrated even we have to go beyond in the present era. There are many impacts that become benchmarks and consequences that need to be the bottom line for the impact on the sustainability of our environment.

Wilderness, Literary Ecology suggests the concept of Wilderness in various ways. The idea of Wilderness refers to the absence of human interference with nature. Wilderness is often viewed as a sacred space, a place of refuge, or even a condition that should not be violated. The Wilderness was a figure of ultimate authenticity. This integrates the entire habitat into an ecological community, which is symbiotic. such as examples of stories of ancestors or discourses of local wisdom who sacred certain areas not to be exploited because of the haunted potential and mystical atmosphere that exists, even though the reality is that if humans exploit the place, the balance of nature will be disturbed. 


\section{VOL. 03 NO. 01 , JUNE 2021}

Apocalypse, defined as an apocalypse which is derived from the ancient Greek word: apocalypses which means to open, literally definition was to reveal knowledge or to remove the veil. In a religious context it is usually the disclosure of something hidden. But in an environmental context it means impact. The classic "Silent Spring" by Rachel Carson (Ashwood-Smith et al., 1977) highlights the dangers of pesticides and sparked intense environmental debate in the twentieth century due to human interference such as nuclear bombs, natural disasters that claimed many living things, terrorism, war, and even epidemics such as the corona virus disease. Lawrence Buell's work on American culture, The Environmental Imagination, states that apocalypse is the single most powerful metaphor that environmental imagination has.(Cunningham \& Storey, 2005)

Dwelling, defined as a temporary home, actually dwellings is not a temporary place in full definition, but implies the erosion of the long number of humans in terms of death, because humans will inevitably die, and new humans are born again and continue to age like that as endless cycle. This temporary home is very broad. In fact, many scientists have developed the theory that one day the earth will no longer be habitable, and humans are persistently trying to explore other planets to live in such as the moon and mars. There are also those who seek alternative solutions by making space ship based that have the same function with earth. But in the end Humanity can't be deceived that other than the earth are not categorize as home. This temporary places means dwelling. There are also those who argue with the term of our motherland which implies those who go far or oversees and leave their motherland but when they are old enough or achieve their goals they will return to their motherland. There are also those who argue that the earth is a dwelling if it is related to the category of the earth which is physical, where everything in physical form will not exist and this cycle has one common point and can only be understood beyond physical form or metaphysical.

Animalism, research related to the relationship between animals and humans in the humanities discourse is divided between the analysis of animal representations in history and culture, and philosophical considerations about the rights held by animals. Just the same with pastoral and unspoiled forests which are inhabited by various kinds of natural animals, animals also have various important functions. The relation between human and animal becomes more powerfull with pandemi because coronaviruses have been identified in bats, and some of these bat coronaviruses may be transmitted to humans either directly or through someintermediate animal hosts.(Wu et al., 2012)

Future the Earth, here is defined as the same imaginary act in order to understand the earth as a fragile totality of which we are part of it or biocentrism and if we do not protect the earth by grasping the earth is monetary wealth only then we will perish together with the earth. However, an imaginary hope is the weakest and most valuable thing to keep thinking that our earth is our real home.

\section{METHOD}

The population of this research totaly was 15 students in the students of Islamic University of Majapahit Mojokerto, Indonesia. The background of the locations was selected based on the researcher who teaech in the same class. The subjects of this research is Literary Theories and Appreciation at fifth smester through Eco Critics Apporach. the research included students (male and female with age range of 16-18 years old).

The type of this research is RND (Research and Development). This research was conducted with the aim of developing and implementing a product as a solution to problems that exist in the world of education in terms of environment. And this research is a development of previous research with the research title "The Implementation of Eco Criticism Approach for Healthy Earth and strengthen the English Writing Skill of Literary Appreciation Class" (Saifulloh, 2019) in the journal IJOEEL: International Journal of English Education and Linguistics. There are several stages used in this research, they are;

Preparation, the stages of this research preparation starting by compiling a research proposal, compiled by the researcher and its member, designing and compiling a draft, outlining the textbook framework developed from research instruments (Lesson Plan for Literary Theories and Appreciation courses) In this case it is carried out by the lead researcher and members, Validating the development of lesson plan into a draft that will be used as a textbook or what researchers call 


\section{VOL. 03 NO. 01 , JUNE 2021}

the first prototype validated by experts and practitioners. In this case it is carried out by the researcher and members.

Implementation, the research that using a model adapted from Plomp development is referred to as a research model Plomp. Based on Plomp and Nieveen, there are three stages in the research development of Model Plomp, namely the preliminary phase of the study (Preliminary Research), phase of development or prototype (Development or Prototyping Phase), and the assessment phase (Assessment Phase) that the total phase will be implemented by the chairman and members.(Plomp \& Nieveen, 2007) This is illustrated in Figure 3.1.

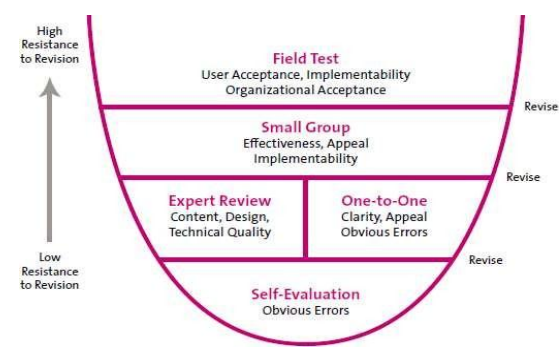

Figure 3.1. Layers of Formative Evaluation of the Plomp Development Model

(Source : Tessmer in Plomp and Nieveen(Plomp \& Nieveen, 2007)

Self-Evaluation, researchers examine or evaluate its own prototype which has been designed in the first research and move to the second prototype which is synchronize with Lesson Plan and the modification of the first research.

Expert Review, at this stage of this research, the experts provide the requested evaluation or provide assessment and suggestions for follow-up and specific knowledge to design the product to determine the weaknesses and advantages, as well as pay attention to specifications of the product that is expected is based on aspects of material, aspect of the contents, aspects language, and summarize as presentation/ graphic aspects.

Evaluation of Individual (One-to-one Evaluation), is carried out against three people participant in the fourth semester in the class of Literary Theories and Appreciation randomly. Participants are students asked to provide comments on the substance of teaching and learning at Literary Theories and Appreciation class. Because of the limitations in Post Corona Virus Disease, the researcher uses Need Analysis randomly in the first meeting via e-learning.

Small Group Evaluation is held by Fives the participant students who have the ability heterogeneous. Participants students learn by using materials teaching the eyes of college Literary Appreciation in circumstances which in the setting resembles the learning in the classroom virtual through the application of e Learning. Participants are students asked to provide ratings to materials teaching the eyes of college Literary Appreciation are already developed.

Field test, at this stage an evaluation of the implementation of learning in an online class is carried out, and an assessment of the teaching materials for the Literary Appreciation course has been completed.

The data analysis of this research sourced from three expert validator and student response and analysis of student activity data in learning. Data from the responses of students in the form of questionnaires were analyzed with the steps as follows:

$$
\text { skor tanggapan }(\%)=\frac{j \text { umlah skor yang didapat }}{\text { jumlah skor maksimal }} \times 100 \%
$$

The percentage that has been obtained is then adjusted with the following parameters according to Arikunto 2006 in (Nurdyansyah \& Mutala'liah, 2015):

$85 \%-100 \%=$ Very Appropriate, $\quad 70 \%-84 \%=$ Appropriate,

$60 \%-69 \%=$ Appropriate enough, $\quad 50 \%-59 \%=$ Less Appropriate $\quad<50 \%=$ inappropriate 


\section{VOL. 03 NO. 01 , JUNE 2021}

Student learning outcomes were analyzed descriptive quantitatively by calculating the average value of the assignment and test scores. The final score or the value of individual student learning outcomes is calculated by the formula;

$N A=\frac{A+2 B}{3} \times 100$
Note: $\quad \mathrm{NA}=$ Final Score $\quad \mathrm{A}=$ Quiz Score $\quad \mathrm{B}$ : Test Score

\section{FINDINGS AND DISCUSION} Findings

After going through the validation test by ecologists, media, and language experts, as well as based on individual or one to one Questionnaire data, small groups and field tests related to teaching materials for Eco Criticism courses. The results obtained in the application of the ecological characteristics of literature which include the main elements, namely Pollution, Position, Pastoral, Wilderness, Apocalypse, Dwelling, Animal, Future the earth. In addition, the results of the analysis are in the form of a percentage which is then classified into the percentage description as follows.

The First validator was Suprapto, S.Pd., M.Si. In terms of his background as educator and his thesis's focus was on the socio-environmental conflict which is related to the Amdahl waste with the title "Gerakan Sosial Masyarakat Sipil dalam Penolakan Pabrik Karet di Desa Medali" and his proceeding which discuss about the green movement of Brantas River with the Title "Implementasi Pelaksanaan Desa Mandiri(DSM): Strategi Pembangunan Pedesaan". Because of the researcher's lack of ecological knowledge so its important to validate this material to be good teaching material. Validation Expert Materials Instructional Course Eco Criticism, has three components namely validation 1 . The Suitability and Description of Matter (Completeness of the material, the material breadth and depth of the material) 2. The Accuracy and Truth Matter (Introduction, importance of literature, the importance of ecology, ecology literature, literary ecological characteristics, appreciation of literary ecology) 3. Learning Support Materials (Accuracy of case examples, accuracy of pictures and literacy narratives, power of terms) Based on the description above, it can be concluded that the assessment by subject teaching material experts is $92.3 \%$. And in the open questionnaire there are several notes to be more popularized in the realm of information technology-based learning media.

\begin{tabular}{|c|c|c|c|}
\hline Expert & Aspect & Criteria & Score \\
\hline \multirow[t]{4}{*}{ Material } & $\begin{array}{l}\text { 1. The } \\
\text { Suitability and Description } \\
\text { of Matterials }\end{array}$ & $\begin{array}{l}\text { (Completeness of the material, the } \\
\text { material breadth and depth of the } \\
\text { material) }\end{array}$ & 92 \\
\hline & $\begin{array}{l}\text { 2. The Accuracy and Truth } \\
\text { Matterials }\end{array}$ & $\begin{array}{l}\text { (Introduction, importance of } \\
\text { literature, the importance of ecology, } \\
\text { ecology literature, literary ecological } \\
\text { characteristics, appreciation of } \\
\text { literary ecology) }\end{array}$ & 93 \\
\hline & 3. Learning Support Materials & $\begin{array}{l}\text { (Accuracy of case examples, accuracy } \\
\text { of pictures and literacy narratives, } \\
\text { power of terms) }\end{array}$ & 95 \\
\hline & Total & & $93,33333 \%$ \\
\hline
\end{tabular}

Tabel 1. The Result of Validation Expert Material

The Second Validator was Akhmad Fatoni, SS., M.Hum. He graduated from State University of Airlangga Surabaya and he is an editor and also a publisher since 2013 until now. Media Expert Validation has three validation components summarized in the following description, 1. Presenting the material (Presentation systematic and presentation order), 2. Presentation Appropriateness (Introduction, Content, and clossing point) 3. Graphics Appropriateness (Book size with ISO standards, cover design related to layout, composition, and letters, Design of book content which contains a reflection of the contents of the book, the harmony of the layout, the completeness of the layout and the typography of the content) Based on the validation results it can be concluded that the evaluation by media experts is $95.3 \%$ And in an open questionnaire there are several notes 


\section{VOL. 03 NO. 01 , JUNE 2021}

that there are not many scientific works that use Literary Ecology as an application in the world of education, and he highly recommends this work as a reference in the field of applied literature.

\begin{tabular}{|c|c|c|c|}
\hline Expert & Aspect & Criteria & Score \\
\hline \multirow{4}{*}{$\begin{array}{l}\text { Graphic } \\
\text { and } \\
\text { Design } \\
\text { of Media }\end{array}$} & 1. Presenting the material, & $\begin{array}{l}\text { (Presentation systematic and } \\
\text { presentation order) }\end{array}$ & 96 \\
\hline & $\begin{array}{l}\text { 2. Presentation } \\
\text { Appropriateness }\end{array}$ & $\begin{array}{l}\text { (Introduction, Content, and clossing } \\
\text { point) }\end{array}$ & 93 \\
\hline & 3. Graphics Appropriateness & $\begin{array}{l}\text { (Book size with ISO standards, cover } \\
\text { design related to layout, composition, } \\
\text { and letters, Design of book content } \\
\text { which contains a reflection of the } \\
\text { contents of the book, the harmony of } \\
\text { the layout, the completeness of the } \\
\text { layout and the typography of the } \\
\text { content) }\end{array}$ & 97 \\
\hline & Total & & $95,33333 \%$ \\
\hline
\end{tabular}

Table 2. The Result of Media Expert Validation

The Third Validator was Syihabul Irfan, M.Hum. He has certified language published by BIPA (Bahasa Indonesia untuk Pennutur Asing) at Language Faculty of State University Jakarta. and cerified phonetic by MLI (Masyarakat Linguistic Indonesia) at Katolik University of Atma Jaya, Kartidaya, and SIL International at RBI (Ruang Bincang Ilmiah) PKKBB Atma Jaya Jakarta. He is the alumnus of University of Indonesia. Validation Expert Language also has a third component that includes the contents validation 1. Suitability (sentence structure, effectiveness of sentences, rigidity, understanding of the message or information, the ability to motivate learners, learner's compliance with intellectual property, and Compliance with the development of emotional Participants) 2. Coherence (coherence and cohesiveness between chapters, coherence and coherence between paragraphs, and coherence and coherence between sentences). 3. Involvement (Creating curiosity, encouraging the ability to ask questions and use case examples with everyday life). Based on the description of the validation, it can be concluded that the assessment by language experts is $92.3 \%$. And in an open questionnaire there are several notes that this teaching material has very interesting and quite valid case examples.

\begin{tabular}{|c|c|c|c|}
\hline Expert & Aspect & Criteria & Score \\
\hline \multirow[t]{2}{*}{ Language } & 1. Suitability & $\begin{array}{l}\text { (sentence structure, effectiveness of } \\
\text { sentences, rigidity, understanding of } \\
\text { the message or information, the } \\
\text { ability to motivate learners, learner's } \\
\text { compliance with intellectual property, } \\
\text { and Compliance with } \\
\text { the development } \\
\text { of emotional Participants) }\end{array}$ & 95 \\
\hline & 2. Coherence & $\begin{array}{l}\text { (coherence and cohesiveness between } \\
\text { chapters, coherence and coherence } \\
\text { between paragraphs, and coherence } \\
\text { and coherence between sentences). }\end{array}$ & 93 \\
\hline
\end{tabular}


VOL. 03 NO. 01 , JUNE 2021

\begin{tabular}{|l|l|l|l|}
\hline 3. Involvement & $\begin{array}{l}\text { (Creating curiosity, encouraging the } \\
\text { ability to ask questions and use case } \\
\text { examples with everyday life) }\end{array}$ & 92 \\
\hline & Total & & $93,33333 \%$ \\
\hline
\end{tabular}

Table 3. The Result of Validation Expert Langue

Those three valadation are not only becomes validator but also a reveiwer and an expert who helps this research inclusively. They helps to give an oppinion and correction regarding the material of Eco Criticsm. They helps to edit and support in focus group discussion three times.

As for individual trials, the researcher did not use a questionnaire because the effectiveness of the work of the questionnaire if it was done on an individual was less effective, so we added some direct questions to obtain more valid data for 3 students. The three students stated that overall they were good with regard to teaching materials. And they add an open statement that literary ecology is best done before appreciating a literary work. They explained that they had to repeat understanding literary works three times before understanding literary ecology. However, after understanding literary ecology they easily understand a literary work and think this method is very good.

The weaknesses that are obtained are only technical matters which happen because students are not accustomed to using e learning. E learning is a virtual educational platform due to the COVID-19 pandemic, which has caused students to not be able to meet face to face with teachers. However, they are helped by teaching materials that explain in stages the steps to understanding a literary work.

The questionnaire for the small scale Student was 7 students with component 1 . Display cover made you interested in studying the material substance of teaching, 2. Topics of discussion/ title of the chapter is already attract the attention you to learn the material more in, 3. The purpose of learning that exist already, enables you to know the ability of what are to be held after following the activities of the learning material that is presented already in accordance with goals learning, 4. The materials were presented already in accordance with the purpose of learning, 5. Summary of the end of the chapter; discussion has been able to increase the understanding about the material that has been studied, 6 . The existence of an evaluation; reflection already can help you gauge the extent to which you understand the material that has been studied, 7 . The language that is used on the grain material is easy to understand the students. The systematic presentation of the material makes it easy for you to understand the whole material in stages. Based on the results of the description, it can be concluded that the questionnaire by 7 students was $7.71 \%$. Even though it has passed the feasibility test, the value obtained is less than the maximum; a revision will be made for teaching materials. Research and development have resulted in material resource that has been validated by expert materials, expert media and expert language, and has been through the process of testing an individual, group small. The field test data can be seen below which consists of the results of the field tests and the test scores, the mean of tests is 87.26 and the mean of the field tests is 87.58 with a percentage value of $87.42 \%$.

By carrying out the theme of environmental literature which was carried out during the pandemic, it is considered very right on target because of its relevance which is in accordance with the relevance and current situation. This is evidenced by the ecological component of literature which has 8 elements Pollution, Position, Pastoral, Wilderness, Apocalypse, Dwelling, Animal, and Future the Earth to be a patterned characteristic that can be used as a benchmark that opens understanding about the environment. Not only that, various due diligence by media, language and environment-related material experts received the maximum due diligence and need further development to become an applicable environmental discourse in the world of education. Finally, there are several layered tests from individual tests, small scale tests and field tests; although the small group test has medium results because this environmental discourse is indeed a symbol and a separate point of view for students to repeatedly understand in appreciating a work of environmental literature.

\section{Discusion}

In this research, the main focus of this research is the development research of the core material in the field of Eco Criticism course. In literary criticism Ecocritics has several characteristics such as Pollution, Position, Pastoral, Wilderness, Apocalypse, Dwelling, Animal, Future and the earth. These characteristics are implemented and developed into an approach in the world of applied literature. The implementation here is intended to provide a literary eco-logic filter before students enjoy a literary works.

There are two processes that students go through in this research. First, students were asked to see literary works of films that have received many awards by the world and full of environmental messages with 


\section{VOL. 03 NO. 01 , JUNE 2021}

the title Wall-e without the ecological literary filter of Eco Criticsm. Based on individual self-evaluation, they have a flat opinion and just enjoy the film without realizing the environmental value and other aspect remains. The second process was they saw a film that has thick environmental values with the title Life of Pi and previously the students accompanied by full understanding related to literary ecology as teaching materials. And after they understand the ecology of literature, some argue from the students that it is necessary to repeat until three times to understand the meaning contained in the literary work trough Eco Criticms. The results of this implementation are obtained from the field test. The specifications for developing teaching materials will be explained as follows;

Pollution,technically, in developing teaching materials, researcher focuses directly on the definition of pollution and implement it in literatury works. From the overall results of the raw data and we conclude, there are several different opinions from the students. There are those who argue that the Pollution in the Wall-E film is in the form of a fully displaced earth's atmosphere with an unused satellite. There are also those who argue that pollution is evidenced by the accumulation of garbage on earth like mountains. And also the contamined the earth with dangerous high contamination.

Position,Position is defined as the condition of the earth when the film is narrated. The students as a whole argue that the earth is not suitable for living. There are dangerous radio active materials that threaten life, not only for humans being but also all living things on the earth. Earth becomes an uninhabited planet and it is only inhabited by a trash robot named Wall-e as a non living being and has no affection of those dangerous radio active.

Pastoral is characterized as the condition of the earth that is depicted in the film in the past. Data taken from the student field test, they felt a bit confused about looking for this data, but some argue of the student namely Erin explain that there is a scene where trash robots see past films in the old Televition where humans can still hold hands to hands to dance happily, lots of green plants grow, and ecosytem in the earth fully co exist with beautful scinery and love..

Apocalypse is defined as a disaster due to massive natural destruction result in natural disasters and climate change. In this film students argue that the apocalypse is represented as large dust of storm. Another argue that this apocalypse happens because there is no water on the earth and plants on the earth. And the disappearance of green hills and mountains on the earth.

Wildernss is defined as sacerd places which function is to naturalize the nature of human intervention. This has created confusion for students because of the wide meaning of the wilderness symbol in the film. There are those who argue that the sacerd place is the earth itself which is full of trash, and because of its high radioactivity, the earth has been abandoned by humans for centuries. So that without realizing it, the earth has become a sacerd place and full of green plants and organizm.

Dwelling is defined as a temporary escaping from home in this term was the earth itself and in the futere human being will came back to its nature the earth. In the film, students argue that Dwelling is reperesentedas a Space Ship inhabited by a fat human who relies on all his life activities with robot and technology. And at the end of the film the humanity realize that technology can't replace the earth, so they came back to the earth at the end.

Animal is defined as a symbol of relationship between humans and animals. In this film students argue that there is only one animal in the film. And the animal is very symbolic in the form of a cockroach, this animal irony insinuates human life that damages the environment with its mountain of garbage.

Future the earth is defined as an imaginary action that hopes that the earth's condition in the future will become a green and beautiful earth. In this film, students argue that there is a moving picture of the latest footage in the film that the earth is slowly being occupied again, civilization begins to develop naturally, human and plant animals can synergize with each other into a harmonious entitiy.

\section{CONCLUSION}

The feasibility level of the development of literary ecology teaching materials in the literary theories and appreciation course for 4th semester students of English language education at the faculty of teacher training and education is in the appropriate category according to the product trial results. To find out the feasibility of this product the researchers conducted an assessment of the experts

The result of the teaching material expert validator was $92.3 \%$, the assessment by the media expert was $95.3 \%$, and the assessment by the linguist was $92.3 \%$. Meanwhile, for the questionnaire test, it could be seen that the questionnaire by 7 students was $7.71 \%$. And the field test data can be seen below which consists of the results of the field tests and the test scores, the mean of tests is 87.26 and the mean of the field tests is 87.58 with a percentage value of $87,42 \%$. 


\section{VOL. 03 NO. 01 , JUNE 2021}

The weaknesses obtained are only technical matters which are because students are not accustomed to using E learning. E learning is a virtual educational platform due to the COVID-19 pandemic, which has caused students to not be able to meet face to face with teachers. So there are a lot of things and intended meaning uncover. However, the student is helped by teaching materials that explain in stages the steps to understanding a literary work.

\section{ACKNOWLEDGEMENTS}

Thousands of thanks due to the dedication of expert who tends to secure their time and power to this research Mr. Syihabul Irfann, M.Hum, Mr. Akhmad Fatorni, SS.,M.Hum, Mr. Deni Mustofa M.Pd.I, and Mr. Suprapto, M.Si. and The researcher would like to express his immense gratitude to both his supporters who have provided insight and expertise that greatly assisted the research

\section{REFFERENCES}

Ashwood-Smith, M. J., Grant, E. L., Heddle, J. A., \& Friedman, G. B. (1977). Chromosome damage in chinese hamster cells sensitized to near-ultraviolet light by psoralen and angelicin. Mutation Research - Fundamental and Molecular Mechanisms of Mutagenesis, 43(3), 377-385. https://doi.org/10.1016/0027-5107(77)90059-8

Central Bureau of Statistics. (2019). Indonesian Environmental Statistics 2019. Badan Pusat Statistik, 1-224. https://www.bps.go.id/publication/2018/12/07/d8cbb5465bd1d3138c21fc80/statistiklingkungan-hidup-indonesia-2018.html

Cunningham, V., \& Storey, J. (2005). Blackwell Manifestos. In Culture.

Garrard, G. (2004). Ecocriticism (the New Critical Idiom). In London and New York: Routledge Taylor \& Francis Group (Vol. 53, Issue 9).

Garrard, G. (2012). Teaching ecocriticism and green cultural studies. In Teaching Ecocriticism and Green Cultural Studies. https://doi.org/10.1057/9780230358393

Nurdyansyah, \& Mutala'liah, N. (2015). Pengembangan Bahan Ajar Modul Ilmu Pengetahuan Alambagi Siswa Kelas IV Sekolah Dasar. Program Studi Pendidikan Guru Madrasa Ibtida'iyah Fakultas Agama Islam Universitas Muhammadiyah Sidoarjo, 41(20), 1-15.

Phillips, D. (1999). Ecocriticism, Literary Theory, and the Truth of Ecology. New Literary History, 30(3), 577-602. https://doi.org/10.1353/nlh.1999.0040

Plomp, T., \& Nieveen, N. (2007). An Introduction to Educational Design Research.

Putry, R. (2019). Nilai Pendidikan Karakter Anak Di Sekolah Perspektif Kemendiknas. Gender Equality: International Journal of Child and Gender Studies, 4(1), 39. https://doi.org/10.22373/equality.v4i1.4480

Saifulloh, A. I. (2019). The Implementation of Ecocriticism Approach for Healthy Earth and strengthen the English Writing Skill of Literary Appreciation Class. 01(02), 10-17.

Wu, K., Peng, G., Wilken, M., Geraghty, R. J., \& Li, F. (2012). Mechanisms of host receptor adaptation by severe acute respiratory syndrome coronavirus. Journal of Biological Chemistry, 287(12), 8904-8911. https://doi.org/10.1074/jbc.M111.325803 